\title{
MODEL MANAJEMEN SEKOLAH MENENGAH ATAS ABAD XXI
}

\author{
Lantip Diat Prasojo
}

FIP Universitas Negeri Yogyakarta (e-mail: lantip@uny.ac.id; HP: 08157964906)

\begin{abstract}
A Model of the Senior High School Management in the $21^{\text {st }}$ Century. Globalization brings about wide impacts, including demands for development in the educational field. The development of secondary education, especially senior high schools, needs to be well planned in order that it can be well implemented. One of the problems arising in the senior high school development is one related to management. This can be solved using a reliable management model, called a model of the senior high school management in the $21^{\text {st }}$ century. This model is based on five principles, i.e.: (1) improvement of the quality of senior high schools, (2) implementation of modern management, (3) implementation of balanced scorecard, (4) implementation of good governance, and (5) application and development of ICT.
\end{abstract}

Keywords: management model, $21^{\text {st }}$ century management system

\section{PENDAHULUAN}

Pengaruh globalisasi sudah merambah berbagai bidang, termasuk bidang pendidikan. Pengaruh globalisasi tersebut perlu diantisipasi oleh dunia pendidikan termasuk pendidikan menengah khususnya Sekolah Menengah Atas (SMA). Usaha pemerintah dalam mengembangkannya dapat juga dilihat dari adanya beberapa proyek peningkatan mutu pendidikan yang salah satunya adalah dengan pembentukan Sekolah Menengah Atas Rintisan Sekolah Berstandar Internasional (SMA RSBI) dan Sekolah Menengah Atas Berstandar Internasional (SMA BI). Program ini menekankan pada pengembangan sarana, persiapan bahan pengajaran dan dukungan konsultan dalam hal pelaksanaan kurikulum, pengembangan buku teks, peningkatan sistem ujian, peningkatan kesempatan studi lanjut guru, peningkatan pembinaan guru, peningkatan supervisi akademik, perawatan preventif, perancangan kembali dan pelaksanaan program laboratorium bahasa, serta mengembangkan model pengembangan dan pelaksanaan manajemen SMA yang Berstandar internasional. Selain itu, usaha-usaha pemerintah dalam mengembangkan SMA sudah dilakukan dengan adanya usaha, seperti melalui hibah, beasiswa, program SMA RSBI, dan program SMA BI.

Kenyataan di lapangan menunjukkan bahwa belum semua SMA bisa menikmati program-program pemerintah tersebut. Hal ini menjadi salah satu penyebab kemajuan pendidikan menengah khususnya SMA masih belum maksimal. Berdasarkan hasil riset Indonesia Corruption Watch (ICW) pada tahun 2010 menyatakan bahwa bantuan RSBI di tingkat SMA banyak digunakan 
untuk berbagai program pembuatan standar kompetensi kelulusan, peningkatkan pendidik dan tenaga pendidik. Tidak ada program yang benar-benar bermanfaat secara langsung kepada siswa (diunduh tanggal 21 Juni 2010 dari: http:/www.jpnn.com/index.php?mib=b erita.detail\&id $=66242)$. Berdasarkan hasil riset ICW di atas menunjukkan bahwa implementasi program-program pemerintah tersebut belum maksimal. Kondisi ini memiliki salah satu dampak bahwa tidak semua SMA memiliki tingkat kelulusan yang mencapai $100 \%$ bahkan ada SMA yang siswanya tidak lulus semua. Selain itu, terdapat juga masalah pemerataan program-program pemerintah tersebut. Memang pada beberapa SMA tertentu mendapatkan program pemerintah tersebut dan memiliki sistem manajemen yang bagus, tetapi banyak SMA yang belum mendapatkan program-program pemerintah tersebut. Berdasarkan uraian dalam pendahuluan sebagaimana tersebut di atas, maka dapat diambil dua masalah yang akan dikaji dalam tulisan ini, yaitu: (1) bagaimana Analisis Sistem Manajemen SMA dari sudut pandang Manajemen Pendidikan Modern?, (2) bagaimana Formulasi Model Manajemen SMA Abad XXI?

\section{PEMBAHASAN}

Prosedur pemecahan masalah adalah dengan memahami secara konsep dan teori yang terkait manajemen pendidikan modern yang meliputi: pembaharuan SMA, Teori Manajemen Abad 21, Konsep Balance Scorecard, Konsep dan Teori Corporate Governance, dan implementasi ICT dalam proses pembelajaran di SMA. Langkah berikutnya adalah melakukan analisis sistem manajemen SMA dari sudut pandang manajemen pendidikan modern sehingga dapat dirumuskan suatu formulasi model manajemen SMA abad XXI.

\section{PEMBAHARUAN SMA}

Kunci pembaharuan SMA dalam masalah ini adalah kecepatan dan ketepatan pembaharuan dalam berbagai aspek di tingkat sekolah. Kepala SMA harus mampu menciptakan pembaharuan dengan cepat sesuai tuntutan globalisasi yang berkembang dengan pesat sehingga sekolahnya mampu menghasilkan lulusan yang sesuai dengan kebutuhan stakeholder. Hal ini perlu dilakukan untuk membangun lompatan sistem menajemen dari sistem manajemen konvensional ke sistem manajemen modern dalam dunia pendidikan. Gambaran lompatan sistem manajemen tersebut dapat dianalogikan dengan teori relativitas dari Albert Einstein (1905), yaitu: $\mathrm{E}=\mathrm{MC}^{2}$ yang mengatakan bahwa setiap masa (benda-benda) jika dilakukan perubahan dengan kecepatan tinggi, maka akan menghasilkan energi yang sangat besar. Dalam rumus tersebut kecepatan menjadi kunci utama, yaitu kecepatan cahaya ( $3 \times 10^{8}$ per detik) dan kecepatan tersebut masih dikuadratkan sehingga kecepatan yang dibutuhkan menjadi ( $9 \times 10^{16}$ per detik). Konsep berfikir dalam teori tersebut sebenarnya dapat diimplementasikan dalam dunia pendidikan untuk menciptakan pembaharuan khususnya pada sistem manajemen SMA. Dengan demikian, pembaharuan pada SMA tersebut perlu kecepatan yang sangat tinggi sehingga menghasilkan suatu model aktual yang 
dapat digunakan dalam memecahkan masalah-masalahbidang pendidikanmenengah.

Berdasarkan pembaharuan SMA tersebut, maka peran Kepala SMA dalam usaha-usaha melakukan pembaharuan disekolahnyauntukmeningkatkan mutu pendidikan menengah, yaitu: (1) merumuskan visi keunggulan dan misi SMA dengan memperhatikan visi dan misi pendidikan nasional; (2) memperhatikan kebutuhan warga sekolah yang terdiri dari: guru, siswa, orangtua, komite sekolah, dan masyarakat sekitar SMA; (3) mengoptimalisasikan peran warga sekolah tersebut dalam rangka pembaharuan menuju pengembangan SMA; (4) mampu menciptakan keterpaduan antara SMA dengan masyarakat sekitar; (5) menciptakan komunikasi yang terbuka dan sinergis di antara warga sekolah; (6) mampu membaca dan memprediksi kebutuhan ICT dalam pembaharuan SMA; (7) mampu membaca kebutuhan stakeholder dan mampu menciptakan kualitas PBM dengan memperdayakan sumber daya yang ada untuk menghasilkan lulusan yang relevan dengan kebutuhan stakeholder; (8) mampu melakukan perubahan dengan sangat cepat untuk menciptakan pembaharuan SMA sehingga dapat mengejar ketertinggalan dengan kemajuan dunia industri; (9) mampu mengambil keputusan dengan cepat dan tepat secara bersama (melibatkan warga sekolah) dalam mengatasi masalah-masalah yang ada; (10) mengimplementasikan transparansi dalam berbagai aspek termasuk bidang keuangan dengan mengacu pada aturan-aturan yang berlaku; (11) mewujudkan akuntabilitas lembaga (SMA) sebagai bentuk tanggung jawab terhadap masyarakat; (12) mampu memotivasi dan berperan sebagai fasilitator dalam rangka menumbuhkan daya inovasi dan kreativitas warga sekolah; (13) memperhatikan nilai-nilai agama dan budaya bangsa Indonesia sebagai fungsi kontrol dalam melakukan pembaharuan untuk pengembangan SMA; (14) Mampu mengembangkan sekolahnya dalam rangka globalisasi.

\section{TEORI MANAJEMEN ABAD XXI}

Peter Drucker (Indrajit \& Djokopranoto, 2006:30) mengatakan, "I am not comfortable with the world manager anymore because it implies subordinates. Manajer yang suka memerintah dalam memimpin sudah tidak diperlukan lagi dalam sistem manajemen abad XXI. Manajer yang dibutuhkan adalah sebagai seorang pimimpin tim dan fasilitator yang selalu fokus dalam mengarahkan organisasi dan timnya pada visi dan misi organisasi. Begitu juga pimpinan SMA hendaknya menjadi seorang pemimpin tim dan fasilitator atau sering disebut dengan leader yang tetap menjaga arah SMA dan timnya tetap pada visi dan misi SMA yang dipimpinnya.

Ciri-ciri manajemen abad XXI sebagaimana dikatakan Indrajit \& Djokopranoto (2006:30-31) adalah sebagai berikut.

> Manajemen harus berhubungan dengan kompetisi global, bukan lagi lokal dan regional.

Manajemen harus menyadari bahwa internasionalisasi sudah terdesak oleh globalisasi.

Manajemen dewasa ini lebih berbasis teknologi, terlebih lagi teknologi informasi. 
Karyawan lebih merupakan mitra daripada bawahan.

Para manajer harus mengelola perubahan.

Kewiraswastaan dewasa ini tetap mendorong kemajuan ekonomi.

Kerjasama tetap merupakan suatu kebutuhan dan keharusan.

Keragaman harus dikelola.

> Para manajer harus mengubah budaya organisasi.

Dengan demikian sistem manajemen SMA abad XXI setidaknya harus memiliki ciri-ciri manajemen abad XXI sebagaimana tersebut di atas.

\section{KONSEP BALANCE SCORECARD DALAM PENDIDIKAN}

Konsep Balanced scorecard tidak hanya digunakan untuk sistem ukuran kerja, tetapi juga digunakan sebagai suatu sistem manajemen. Alasannya adalah pengembangan sistem pengukuran sekaligus dapat digunakan sebagai sarana, yang pada hakekatnya menyangkut sistem manajemen, khu- susnya manajemen strategis. Menurut Indrajit \& Djokopranoto (2006:118), sarana-sarana dimaksud dapat dikelompokkan menjadi empat hal pokok, yaitu: (1) menjelaskan dan menerjemahkan visi dan strategi; (2) mengomunikasikan dan menghubungkan tujuan strategi dan ukuran; (3) merencanakan, menetapkan target, dan menyelaraskan inisiatif strategi; (4) melancarkan umpan balik dan penyempurnaan strategi. Balanced scorecard adalah alat manajemen (management tool) yang menerjemahkan visi, misi dan strategi organisasi ke dalam satu set pengukuran kinerja komprehensif untuk menghasilkan kerangka pengukuran kinerja organisasi melalui beberapa perspektif: finansial, customer, proses bisnis internal, serta pembelajaran dan pertumbuhan. Evaluasi dan pengukuran kinerja yang biasanya dilakukan dalam pengendalian manajemen harus dilakukan secara berimbang (balanced) untuk keempat perspektif tersebut.

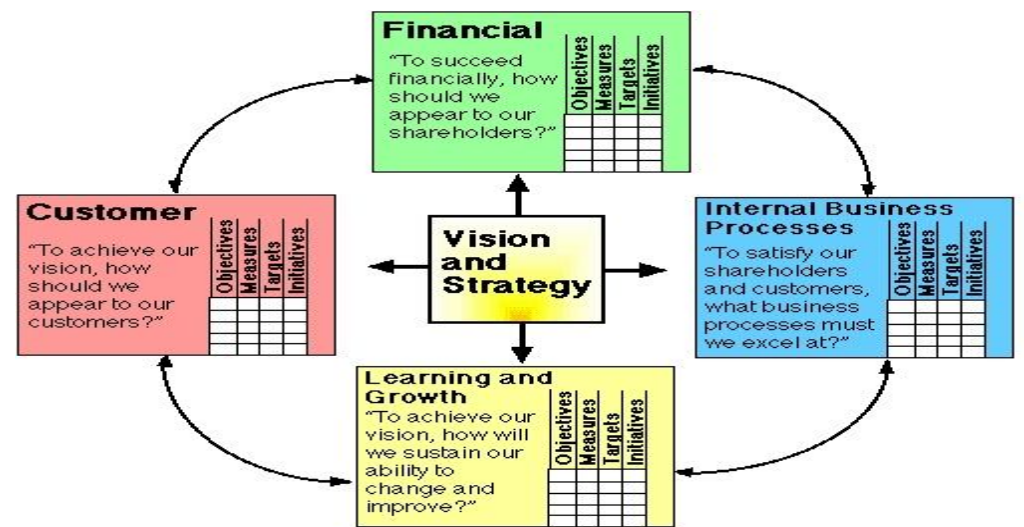

Gambar 1. Konsep Balance Scorecard (Sumber: Vincent Gasperst, 2002)

Kerangka tersebut menggambarkan bahwa agar sistem manajemen strategi dapat berjalan dengan baik, maka visi, misi, dan strategi organisasi harus di- 
terjemahkan ke dalam empat perspektif tersebut. Dari tiap-tiap perspektif, harus ditunjukkan tujuan (objectives), ukuranukuran (measures) kinerja yang dipergunakan, target yang akan dicapai, dan inisiatif strategi yang harus dilakukan untuk mencapai target yang telah ditetapkan sekaligus untuk mencapai misi organisasi. Kemampuan organisasi untuk dapat menerjemahkan visi dan misi organisasi ke dalam tindakan nyata yang terukur sangat menentukan keberhasilan implementasi strategi tersebut.

Visi organisasi yang menggambarkan pandangan jauh ke depan mengenai "apa yang akan terjadi di masa depan dan kemana organisasi akan dibawa" akan sangat menentukan rumusan misi organisasi. Selanjutnya, rumusan misi akan dipergunakan sebagai dasar utama dalam penyusunan dan implementasi setiap program/tindakan/kegiatan. Hal ini dapat dilakukan bila terjadi proses sharing dan internalisasi visi dan misi tersebut ke dalam diri setiap individu anggota organisasi. Kondisi ini mengakibatkan semua anggota organisasi yang terlibat dalam implementasi program/kegiatan tersebut harus memahami visi dan misi organisasi tersebut dan senantiasa memiliki pemahaman serta komitmen kuat untuk mencapai misi organisasi. Dengan demikian, pelaksanaan program kerja dan proyek organisasi tersebut, termasuk penganggarannya, harus senantiasa didorong oleh keinginan untuk mencapai misi organisasi.

Pengendalian keuangan dengan menerapkan value for money audit sangat diperlukan untuk menjamin efisiensi dan efektivitas penggunaan dana ma- syarakat. Pelanggan dalam sektor publik adalah masyarakat secara luas, yang membutuhkan barang dan jasa (termasuk infrastruktur dan fasilitas publik) yang disediakan oleh pemerintah dalam rangka meningkatkan kesejahteraan rakyat.

Indikator-indikator yang dipergunakan untuk mengukur upaya peningkatan kesejahteraan adalah menurunnya tingkat kemiskinan, menurunnya angka kematian sebagai hasil dari peningkatan layanan kesehatan, meningkatnya tingkat pendidikan masyarakat, dan lain-lain. Loyalitas dan kepercayaan masyarakat terhadap organisasi pemerintah merupakan tema stratejik yang harus menjadi pedoman dalam setiap perumusan kebijakan. Hal ini akan tercapai apabila terdapat dua hal, yaitu: (1) pembangunan dilakukan betul-betul untuk meningkatkan kesejahteraan rakyat, (2) pemerintah melaporkan hasil-hasil pembangunan berikut pengelolaan keuangannya secara akuntabel. Bila ini terjadi, maka kesadaran masyarakat untuk membayar pajak akan meningkat dan kredibilitas pemerintah pun akan terpelihara.

Intisari dari perspektif proses bisnis internal adalah "inovasi". Dalam organisasi bisnis, proses inovasi berkelanjutan (ongoing inovation) diperlukan perusahaan agar dapat memenangkan persaingan masa depan. Artinya, dalam setiap rangkaian aktivitas yang dilakukan oleh organisasi dalam menghasilkan barang dan jasa harus senantiasa meningkatkan "nilai" bagi pengguna. Pada organisasi pemerintahan, pemikiran ini harus diterjemahkan sebagai upaya untuk melakukan peningkatan kua- 
litas layanan secara berkelanjutan (continuous quality improvement) kepada masyarakat. Hal ini dapat diwujudkan dengan cara pemberian layanan publik yang lebih efisien, praktis dan adil.

\section{KONSEP DAN TEORI CORPORATE GOVERNANCE}

Dalam kajian ini, kita perlu mengetahui definisi Corporate Governance sebagai berikut. Clark (1983) membagi governance dalam pendidikan menjadi: (1) education-by-laws; (2) rules and regulations; (3) strategic plan; (4) organizational design; (5) institutional system of management; (6) leadership; dan (7) decision making system.

Corporate Governance is the system by which companies are directed and controlled (OECD dalam Indrajit \& Djokopranoto, 2006:251). Selain itu, menurut Wolfensohn (Indrajit \& Djokopranoto, 2006: 251), corporate governance is about promoting corporate fairness, transparency, accountability. Dengan demikian, dapat disimpulkan bahwa corporate governance adalah suatu sistem manajemen yang berlandaskan tugas dan tanggung jawab, kebutuhan stakeholders, keadilan, transparansi, akuntabilitas dan pengawasan.

Prinsip-prinsip Corporate Governance menurut OECD ada lima prinsip utama dan sekaligus sebagai aspek dasar corporate governance, sebagai berikut.

$>$ Perlindungan hak-hak pemegang saham (the rights of shareholders).

> Perlakuan yang sama terhadap seluruh pemegang saham (the equitable treatment of shareholders).
Peranan stakeholders yang terkait dengan perusahaan (the role of stakeholders).

Pengungkapan dan transparansi (disclosure and transparency).

Tanggung jawab Dewan Direksi (the responsibilities of the Board).

\section{IMPLEMENTASI ICT DALAM PRO- SES PEMBELAJARAN DI SMA}

Sistem manajemen pendidikan di SMA juga harus menggunakan dan mengadaptasi perkembangan teknologi yang sangat pesat khususnya Teknologi Informasi dan Komunikasi (TIK) dalam proses pembelajaran. Hal ini, sesuai dengan pendapat Hall (Allen, 2002: 147) yang menyatakan:

"When we think about corporate universities and technology, it is important to think in terms of learning environments. The technology of the internet not only has made more learning available to more people, but also has changed the way we learn."

Teknologi informasi adalah suatu bidang ilmu pengetahuan yang perkembangannya semakin pesat dari tahun ke tahun (Thabratas T., 2002:1). Teknologi informasi mencakup bidang teknik informatika yang merupakan ilmu pengetahuan yang mencakup berbagai hal seperti: sistem informasi manajemen yang berbasis komputer, LAN (Local Area Network), MAN (Metropolitan Area Network), WAN (Wide Area Network), dan internet. Teknologi informasi sebagai ilmu pengetahuan sangat luas pokok bahasannya sehingga tidak hanya informatika saja yang menjadi pokok bahasannya. 
Implementasi teknik informatika dalam SMA biasanya terkait dengan pemanfaatan LAN, WAN, dan internet untuk keperluan pendidikan, seperti: Siakad (Sistem Informasi Akademik), Sikeu (Sistem Informasi Keuangan), dan lain-lain. Secara umum implementasi teknik informatika terkait langsung dengan Sistem Informasi Manajemen (SIM). Sistem informasi manajemen adalah sebagai suatu sistem berbasis komputer yang menyediakan informasi bagi beberapa pemakai dengan kebutuhan yang diinginkan (McLeod, Jr., 2001: 327).

E-learning adalah model pembelajaran yang memanfaatkan teknologi internet untuk penyampaian materi belajarnya. Ada beberapa istilah yang perlu dijelaskan agar didapatkan pengertian yang utuh tentang wilayah dari e-Learning. Istilah yang lain meliputi distance learning, distance education, telelearning, online learning dan e-training.

Telelearning merupakan hubungan diantara orang dan sumber yang menggunakan media teknologi komunikasi dan belajar sebagai tujuannya (Munir, 2008). Online-learning sama dengan webbased learning. Online learning merupakan pemanfaatan sebagian dari pembelajaran berbasis teknologi dan menggambarkan pembelajaran lewat internet, intranet atau extranet.

Pengertian e-learning sebagai berikut, e-learning merupakan pembelajaran berbasis teknologi, mencakup sejumlah aplikasi dan proses, termasuk pembelajaran berbasis komputer, pembelajaran berbasis web, virtual classrooms dan digital collaboration. Ada istilah lain yaitu e-training yang menggambarkan suatu perusahaan atau lembaga sebagai penyelenggara training menggunakan $e$ learning.

Distance learning adalah suatu proses membawa informasi yang interaktif dan informasi pembelajaran yang ditujukan kepada siswa di suatu waktu, tempat dan tampilan (bentuk) yang tepat. Distance education adalah suatu situasi belajar antara tutor dan siswa yangdipisahkanolehwaktu atau tempat. Kontrol pembelajaran lebih besar berada pada siswa dari pada tutor, dan komunikasi antara tutor/guru dan siswa menggunakan media berteknologi komunikasi (Munir, 2008).

Untuk pengembangan sistem Jaringan TIK (e-Learning), diperlukan perangkat keras penunjang terutama komputer sebagai peralatan kunci yang harus ada.Jumlah perangkat komputer dalam sebuah laboratorium pengendali tentunya akan dapat memudahkan pengaksesan seluruh materi pembelajaran yang telah dikembangkan. Selain itu, diperlukan jaringan komputer yang handal, seperti LAN, WAN, dan MAN. Adanya sistem koneksi yang bagus dengan jaringan internet sehingga bisa mengakses dunia global.

\section{PENGEMBANGAN KREATIVITAS DAN INOVASI DI SMA}

Pengembangan kreativitas dan inovasi di SMA dilakukan dengan menanamkan pola pikir di luar kotak artinya berfikir tidak seperti biasanya dalam menyelesaikan masalah sehingga muncul berbagai alternatif pemecahannya, perilaku kreatif, inovatif, komitmen, berani mengambil resiko dan kegagalan. Agar pengembangan kreativitas dan 
inovasi dapat berjalan dengan baik di SMA, maka kepala SMA harus melakukan hal-hal berikut.

> Mampu menciptakan inovasi dan kreatifitas yang berguna bagi pengembangan SMA.

> Bekerja keras untuk mencapai keberhasilan SMA sebagai organisasi pembelajaran yang efektif.

> Memiliki motivasi yang kuat untuk mencapai kesuksesan dalam melaksanakan tugas pokok dan fungsi sebagai pemimpin SMA.

> Pantang menyerah dan selalu mencari solusi terbaik dalam menghadapi kendala SMA.

$>$ Memiliki naluri kewirausahaan sebagai sumber belajar siswa, dan

Memberikan keteladanan bagi para guru khususnya mengenai kompetensi kewirausahaan.

\section{ANALISIS PEMBAHARUAN SMA}

Pembaharuan SMA memiliki karakteristik sebagai berikut: kecepatan dalam menciptakan perubahan dan pengambilan keputusan bersama, akuntabilitas, transparansi, inovasi, kreativitas, visi dan misi sekolah, memperhatikan kebutuhan warga sekolah (guru, siswa, komite, dan masyarakat sekitar sekolah), memperhatikan kebutuhan TI (teknologi informasi), dan relevansi dengan kebutuhan stakeholder (dunia industri). Model pembaharuan untuk pengembangan SMA meliputi empat proses utama, yaitu: (1) kemampuan untuk menciptakan perubahan dan pengambilan keputusan bersama dengan sangat cepat dan tepat untuk memecahkan masalah-masalah yang didasarkan pada kebutuhan stakeholder; (2) adanya akun- tabilitas, transparansi, penciptaan inovasi, dan kreativitas; (3) proses pembaharuan SMA harus disesuaikan dengan nilai-nilai agama dan budaya bangsa Indonesia; (4) pembaharuan harus mengakomodir Sistem Pendidikan Nasional (SPN) yang desentralistis sehingga pembaharuan bisa mencapai daerah-daerah kabupaten/kotadi seluruh Indonesia dengan cara: (a) merubah mindset kepala SMA akan pentingnya pembaharuan melalui pelatihan, seminar dan workshop;(b)membangun budaya yang adaptif terhadap perubahan melalui penanaman kesadaran dan sosialisasi secara kontinyu sehingga timbul kebiasaan-kebiasaan yang menerima adanya perubahan; (c) sosialisasi pentingnya implementasi SPN dalam peningkatan mutu pendidikan di SMA-SMA.

\section{ANALISIS SISTEM MANAJEMEN SMA DALAM KONSEP MANAJE- MEN ABAB XXI}

Dalam pembangunan pendidikan suatu bangsa perlu adanya sistem manajemen pendidikan yang handal (efektif dan efisien) sehingga diharapkan mampu menghadapi persaingan global yang sangat pesat dan dapat mengikuti perkembangan ilmu pengetahuan dan teknologi (Iptek). Terkait dengan manajemen pendidikan di SMA, maka manajemen pendidikan yang handal tersebut dalam kerangka governance pendidikan menengah yang merupakan proses sistem manajemen kelembagaan yang berbasis pada, yaitu: (1) keadilan dan persamaan; (2) mutu yang tinggi dan relevan; (3) professionalism yang kaya dan tidak kering; (4) keterbukaan, pemberdayaan, partisipasi, dan keung- 
gulan (Fakry Gaffar, 2000). Selain itu, manajemen pendidikan di SMA juga harus menggunakan dan mengadaptasi perkembangan teknologi yang sangat pesat khususnya teknologi informasi dan komunikasi (TIK) dalam proses pembelajaran. Dengan demikian dalam suatu SMA keberadaan teknologi dalam manajemen pendidikan khususnya manajemen pembelajaran menjadi sangat penting karena teknologi khususnya teknologi internet dapat menyediakan sumber belajar yang beraneka ragam dan dapat merubah serta mengembangkan cara belajar kita.

Adapun sembilan manajemen SMA abad XXI seperti yang diungkapkan di antaranya, (1) manajemen harus berhubungan dengan kompetisi global, bukan lagi lokal dan regional. (2) Manajemen harus menyadari bahwa internasionalisasi sudah terdesak oleh globalisasi. (3) Manajemen dewasa ini lebih berbasis teknologi, terlebih lagi teknologi informasi. (4) Pimpinan dan bawahan berperan sebagai mitra dalam bekerja. (5) Para pimpinan lembaga pendidikan harus mengelola perubahan. (6) Kewirausahaan dewasa ini tetap mendorong kemajuan ekonomi. (7) Kerjasama tetap merupakan suatu kebutuhan dan keharusan. (8) Keragaman harus dikelola. (9) Para pimpinan harus mengubah budaya organisasi.

Peran manajemen abad XXI dalam SPN yang desentralistis didasarkan pada ciri-ciri manajemen abad XXI. Sistem pendidikan nasional yang desentralistis dapat mengimplementasikan manajemen abad XXI dari tingkat nasional sampai dengan daerah-daerah kabupaten/kota di seluruh Indonesia. Im- plementasi manajemen abad XXI tersebut dilakukan secara bertahap sesuai dengan situasi dan kondisi daerah masing-masing. Adapun beberapa cara yang dapat dilakukan adalah (a) mengubah mindset kepala SMA tentang manajemen modern melalui pelatihan, seminar dan workshop; (b) membangun budaya manajemen modern melalui penanaman kesadaran dan sosialisasi secara kontinyu oleh Kepala SMA; (c) sosialisasi pentingnya implementasi manajemen modern dalam peningkatan mutu pendidikan di SMA.

\section{ANALISIS SISTEM MANAJEMEN SMA DALAM KONSEP BALANCE SCORECARD}

Konsep Balanced scorecard merupakan suatu sistem manajemen karena pengembangan sistem pengukuran sekaligus dapat digunakan sebagai sarana, yang pada hakekatnya menyangkut sistem manajemen, khususnya manajemen strategis. Sarana-sarana tersebut dapat dikelompokkan menjadi empat hal pokok, yaitu: 1) menjelaskan dan menerjemahkan visi dan strategi; 2) mengomunikasikan dan menghubungkan tujuan strategi dan ukuran; 3) merencanakan, menetapkan target, dan menyelaraskan inisiatif strategi; 4) melancarkan umpan balik dan penyempurnaan strategi (lihat bagan di bawah). 


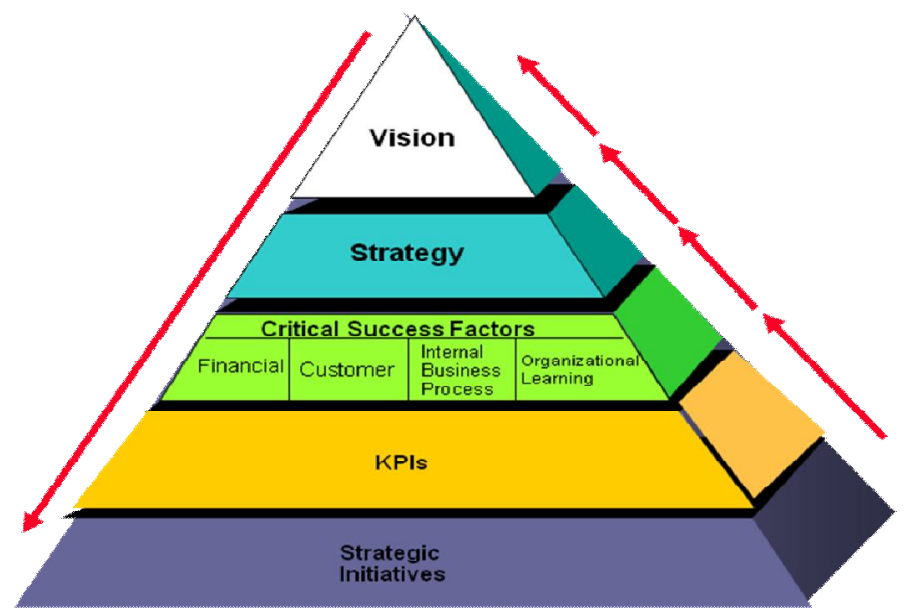

Gambar 2. Sistem Manajemen SMA dalam Konsep Balance Scorecard Sumber: Kaplan, S Robert. David P Norton (1996)

Peran konsep Balance Scorecard dalam SPN yang desentralitis berdasarkan pada empat hal pokok sebagai mana tercantum dalam Gambar 2 di atas. Sistem Pendidikan Nasional yang desentralistis harus memperhatikan visinya sehingga mampu diterjemahkan oleh daerah-daerah di seluruh Indonesia meskipun melalui tahapan-tahapan tertentu. Pemerintah pusat dan daerah harus mengkomunikasikan tujuan dan strategi yang akan dilakukan agar ada kesesuaian antara pemerintah pusat dan daerah. Pemerintah pusat harus melibatkan pemerintah daerah dalam merencanakan, menetapkan target, dan menyelaraskan inisiatif strategi dalam pengembangan pendidikan. Pemerintah daerah perlu melancarkan umpan balik, menggambarkan secara kontekstual sesuai dengan kondisinya dan penyempurnaan strategi yang dapat diterima dan dikembangkan bersama dengan pemerintah pusat. Sinkronisasi dilakukan dengan melibatkan Dinas Pendidikan dan SMA melalui forum Musyawarah
Kerja Kepala Sekolah (MKKS) dalam membangun sistem Manajemen Berbasis Sekolah (MBS). Hal-hal dalam sinkronisasi ini adalah visi dan strategi SMA, tujuan strategi dan ukuran, target dan inisiatif strategi, umpan balik dan penyempurnaan strategi.

\section{ANALISIS SISTEM MANAJEMEN SMA DALAM GOOD GOVERNANCE DAN ICT}

Untuk dapat berkembang, SMA abad XXI juga harus mengadaptasi dan menerapkan prinsip-prinsip good governance, yaitu selalu memperhatikan aspek seperti: transparency, accountability, responsibility, independency dan fairness. Oleh karena itu, SMA harus memiliki akses terhadap data dan informasi yang cepat dan tepat untuk mendukung indikator kinerja atau performa SMA dalam konsep good governance. Data dan informasi yang cepat dan akurat hanya dapat diperoleh jika SMA tersebut memanfaatkan kelebihan ICT dalam sistem manajemennya sehingga memudahkan 
pemimpin SMA untuk mengambil keputusan (pemanfaatan sistem informasi manajemen) dan atau guru dan siswa dapat mengakses informasi dengan mudah dalam proses pembelajaran (pemanfaatan e-learning) atau kepentingan yang lain seperti internet, WAN dan LAN.

Peran good governance dan implementasi ICT dalam SPN yang desentralitis sangat diperlukan sebab dengan adanya pemerintah yang bersih, maka SPN yang desentralitis akan berjalan dengan baik. Implementasi ICT juga sangat dibutuhkan dalam semua aspek kehidupan termasuk dunia pendidikan. Implementasi ICT sangat membantu dalam dunia pendidikan dalam hal kecepatan dan ketepatan, desain yang menarik, dan lain-lain. Proses pembelajaran yang berbasis ICT biasanya lebih menarik dan lebih cepat diakses siswa, seperti: penggunaan e-learning, media pembelajaran, pemanfaatan internet, dan lain-lain.

\section{FORMULASI MODEL MANAJEMEN SMA ABAD 21}

Formulasi model manajemen SMA abad XXI ini didasarkan pada kajian dan analisis sistem manajemen pendidikan modern yang meliputi: pembaharuan SMA, Teori Manajemen Abad XXI, Konsep Balance Scorecard, Konsep dan Teori Corporate Governance, implementasi ICT dalam proses pembelajaran di SMA, dan pengembangan budaya kewirausahaan di SMA serta menjalin kerjasama yang erat dengan dunia industri. Hasil analisis tersebut dikaitkan dengan sistem manajemen pada tingkat sekolah (SMA) sehingga dapat diformulasikan model manajemen SMA abad XXI sebagai berikut.

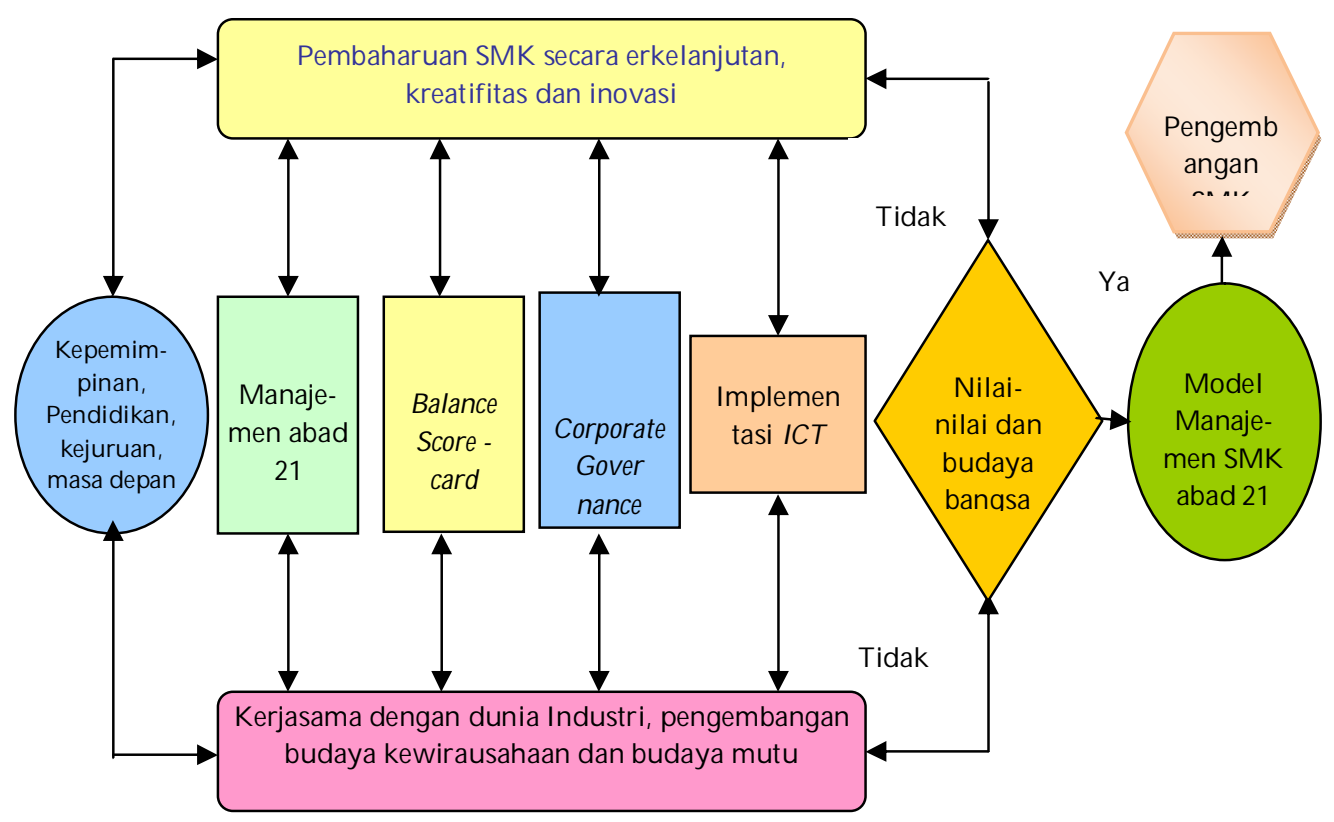

Gambar 3. Model Hipotetik Manajemen SMA Abad XXI

(Model Berlaku pada Tingkat Sekolah) 
Model manajemen SMA abad XXI tersebut bukan merupakan satu-satunya model yang dapat menyelesaikan seluruh permasalahan yang ada di SMA. Model tersebut merupakan salah satu strategi dari sisi manajemen untuk menyelesaikan sebagian permasalahan SMA. Model tersebut diformulasikan berdasarkan kajian dan analisis sistem manajemen pendidikan modern yang dikaitkan dengan fakta-fakta di lapangan. Kepemimpinan pendidikan menengah masa depan merupakan pengambil kebijakan yang memiliki peranan penting dalam membangun sistem manajemen SMA abad XXI. Sistem manajemen tersebut harus memperhatikan pembaharuan SMA secara berkelanjutan yang berorientasi mutu pendidikan melalui peran kepala SMA dalam pembaharuan dan mewujudkan kreativitas serta inovasi warga SMA. Kerjasama dengan dunia industri perlu dibangun secara erat. Pengembangan budaya kewirausahaan dan budaya mutu di SMA perlu dilakukan melalui penanaman kesadaran dan sosialisasi kepada warga SMA. Kajian dan analisis sistem manajemen abad XXI akan menghasilkan ciri-ciri manajemen modern di SMA yang dapat digunakan sebagai parameternya. Kajian dan analisis Corporate Governance yang memiliki prinsip-prinsip good governance yang selalu memperhatikan aspek seperti: transparency, accountability, responsibility, independency dan fairness. Implementasi ICT dalam proses pembelajaran di SMA sangat diperlukan dalam mendukung sistem manajemen SMA abad XXI sehingga dapat mengikuti perkembangan ber- bagai macam teknologi dan globalisasi yang sangat pesat. Semua komponenkomponen dalam model manajemen SMA abad XXI saling berkaitan satu sama lain dan dikendalikan dengan nilai-nilai agama dan budaya Bangsa Indonesia sehingga dapat menghasilkan model manajemen SMA modern yang berdasarkan karakteristik bangsa Indonesia. Dengan model manajemen SMA abad XXI tersebut diharapkan dapat mengembangkan SMA dalam rangka meningkatkan mutu pendidikan nasional.

\section{KESIMPULAN}

Berdasarkan konsep, teori-teori, kajian kritis dan analisis sistem manajemen pendidikan modern sebagaimana tersebut di atas, maka dapat disimpulkan bahwa dalam formulasi model pada level sekolah, yaitu model manajemen SMA abab XXI setidaknya harus memperhatikan lima hal pokok. Adapun lima hal pokok tersebut adalah (1) pembaharuan SMA yang berkelanjutan dalam rangka meningkatkan mutu pendidikan; (2) implementasi sistem manajemen abad XXI dengan mempertimbangkan peran SMA dalam membangun MBS di SMA; (3) implementasi sistem manajemen SMA dalam kerangka konsep balance scorecard dengan melakukan sinkronisasi terhadap MBS; (4) implementasi sistem manajemen SMA dalam kerangka good governance; dan (5) implementasi sistem manajemen SMA yang adaptif dengan perkembangan ICT.

Fungsi pengendalian yang didasarkan pada nilai-nilai agama dan budaya 
Bangsa Indonesia sangat diperlukan agar sistem manajemen SMA yang dibangun terarah. Nilai-nilai agama dan budaya Bangsa Indonesia menjadi karakter penting dalam model menajamen SMA abad XXI sehingga implementasinya sesuai dengan situasi dan kondisi serta karakter Bangsa Indonesia.

\section{UCAPAN TERIMA KASIH}

Terima kasih diucapkan kepada tim Redaktur dan staf Jurnal Cakrawala Pendidikan Universitas Negeri Yogyakarta yang telah member kesempatan untuk mempublikasikan artikel ini. Mudahmudahan artikel ini mampu memberkan sedikit pencerahan kepada pembaca dalam merumuskan kebijakan pendidikan di Indonesia.

\section{DAFTAR PUSTAKA}

Allen, Mark. 2002. The Corporate University: Designing, Managing, and Growing a Successful Program. New York: AMACOM.

Azmiar, Fahmi. 2007. E-Learning - Understanding its True Business Value and Opportunity. dari http://www.ekofeum.or.id. Diakses tanggal 17 Juni 2007.

Clark, Burton R. 1983. The Higher Education System: Academic Organization in Cross-National Perspective. California: University of California Press.

Departemen Pendidikan Nasional. 2003. Undang-Undang Republik Indonesia Nomor 20 Tahun 2003 tentang Sis- tem Pendidikan Nasional. Bandung: Citra Umbara.

Einstein A. 1905. Special Theory of Relativity. http:/hobelprize.org/nobel prizes/physics/aureates/1921/einstein-bio.html. Diakses Tanggal 4 Mei 2008.

Gaffar, M. Fakry. 2000. Pembiayaan Pendidikan: Permasalahan dan Kebijaksanaan dalam Perspektif Reformasi Pendidikan Nasional. Bandung: IKIP Bandung.

Gasperst, Vincent. 2002. Balance Scorecard With Six Sigma. Terjemahan: Balance Scorecard Dengan Six Sigma. Jakarta: Gramedia Pustaka Utama.

Indrajit R.E, \& Djokopranoto, R. 2006. Manajemen Perguruan Tinggi Modern. Yogykarta: Penerbit Andi Offset.

Kaplan, S Robert. David P Norton. 1996. Balance ScoreCard, Terjemahan: Menerapkan Strategi Menjadi Aksi. Jakarta: Erlangga.

Munir. 2008. Kurikulum Pembelajaran Berbasis Teknologi Informasi. Bandung: PT. Remaja Rosda Karya.

Usman, Husaini. 1998. Kepemimpinan Entrepreneur di Pendidikan Menengah. Bandung: CV Alfabeta. 